\title{
Communication
}

\section{New $\beta$-Carotene-Chitooligosaccharides Complexes for Food Fortification: Stability Study}

\author{
Alma Bockuviene ${ }^{1,2}$ and Jolanta Sereikaite ${ }^{1, *}$ (1) \\ 1 Department of Chemistry and Bioengineering, Vilnius Gediminas Technical University, \\ 10221 Vilnius, Lithuania; alma.bockuviene@chf.vu.lt \\ 2 Department of Polymer Chemistry, Institute of Chemistry, Vilnius University, 01513 Vilnius, Lithuania \\ * Correspondence: jolanta.sereikaite@vgtu.lt
}

Received: 8 May 2020; Accepted: 9 June 2020; Published: 10 June 2020

\begin{abstract}
The application of $\beta$-carotene in food industry is limited due to its chemical instability. The drawback may be overcome by designing new delivery systems. The stability of $\beta$-carotene complexed with chitooligosaccharides by kneading, freeze-drying and sonication methods was investigated under various conditions. The first-order kinetics parameters of the reaction of $\beta$-carotene degradation were calculated. The complexation improved the stability of $\beta$-carotene at high temperatures and ensured its long-term stability in the dark at $4{ }^{\circ} \mathrm{C}$ and $24{ }^{\circ} \mathrm{C}$, and in the light at $24^{\circ} \mathrm{C}$. In water solutions, the best characteristics were exhibited by the complexes prepared by freeze-drying and sonication methods. In the powder form, the complexes retained their colour for the period of the investigation of four months. The calculated total colour differences of the complexes were qualified as appreciable, detectable by ordinary people, but not large. Therefore, $\beta$-carotene-chitooligosaccharides complexes could be used as a new delivery system suitable for food fortification.
\end{abstract}

Keywords: $\beta$-carotene-chitooligosaccharides complexes; thermal and long-term stability; UV irradiation; degradation kinetics; colour changes

\section{Introduction}

$\beta$-Carotene is a natural pigment belonging to the carotenoids family. It is composed of a polyene system with eleven conjugated double bonds and a $\beta$-ring at each end of the chain. Humans are unable to synthesize $\beta$-carotene in their bodies. Thus, it is obtained from the diet. $\beta$-Carotene is a precursor of vitamin A and has other biological activities that contribute to human health [1,2]. It exhibits high antioxidant activity [3]. The consumption of $\beta$-carotene is also associated with the reduced risk of cardiovascular diseases [4,5], cancer [6,7], type 2 diabetes [8,9] and the prevention of age-related macular degeneration $[10,11]$. Therefore, there is an increasing interest in the fortification of food with $\beta$-carotene. However, $\beta$-carotene is insoluble in water and has low chemical stability [12,13]. Therefore, its application is limited especially in water-based food.

The encapsulation of $\beta$-carotene using various techniques and materials is a first choice to overcome these drawbacks [14-16]. Emulsion-based systems, i.e., nano/microemulsions of oil-in-water type are one of the most investigated and utilized colloidal systems for $\beta$-carotene encapsulation and delivery $[17,18]$. Recently, an effective encapsulation technology based on amylose inclusion complex with amphiphilic compound has been proposed and used for the incorporation of $\beta$-carotene as a guest molecule. The amylose-surfactant- $\beta$-carotene and amylose-ascorbyl palmitate- $\beta$-carotene ternary systems have been developed, and the stability of encapsulated $\beta$-carotene has been improved [19]. The encapsulation of $\beta$-carotene within apoferritin nanocages can also be regarded as inclusion 
complexation. The thermal stability of encapsulated $\beta$-carotene has been markedly improved. Moreover, such carotenoid-containing nanocomposites are water-soluble [20].

Previously, we prepared $\beta$-carotene-chitooligosaccharides complexes (CAR-CHIOS) by the mechanochemical methods, i.e., kneading, freeze drying and sonication [21]. To the best of our knowledge, the synthesis of CAR-CHIOS complexes was presented for the first time. The highest complexation yield and water solubility and the lowest hydrodynamic radius were found for complexes prepared by freeze-drying and sonication methods. Moreover, we determined that the complexation did not cause the loss of the antioxidant activity of $\beta$-carotene. The carotenoid was complexed with a carrier which itself has biological activities and is considered as a component of functional food [22]. The application of CAR-CHIOS complexes can result in the synergistic effect. CHIOS exhibit anti-oxidant, anti-inflammatory and anti-cancer activities [22,23], positively affect probiotic bacteria [24] and have antimicrobial activity [25]. Moreover, chitosan, from which CHIOS are produced by enzymatic or chemical hydrolysis is approved as a food additive and introduced in the European Pharmacopeia and the US National Formulary in 2008 and 2011, respectively. Taken together, CAR-CHIOS complexes could be in future a new technology for $\beta$-carotene delivery. [26]. However, for the application of CAR-CHIOS complexes, the knowledge on its stability under various conditions is of the primary importance. The complexation of carotenoids with carbohydrates by mechanochemical methods are not largely investigated and the impact of this techniques on the properties of carotenoids are not fully understood. Previously, Polyakov et al. [27] complexed mechanochemically canthaxanthin with arabinogalactan and the water solubility of the carotenoid was increased.

Therefore, this study aims for the evaluation of the effect of temperature, $\mathrm{pH}$ and UV irradiation on CAR-CHIOS complexes prepared by mechanochemical methods. The changes of the colour of complexes in the form of powder under the long-term storage conditions were also presented.

\section{Materials and Methods}

\subsection{Materials}

$\beta$-carotene was purchased from Sigma-Aldrich. Chitooligosaccharides (CHIOS) were prepared by the acid hydrolysis of chitosan $\left(\mathrm{M}_{\mathrm{W}} 500,000 \mathrm{Da}\right)$ as previously described [21] The average molecular weight of obtained chitooligosaccharides was $3.8 \mathrm{kDa}$, and the degree of deacetylation was $80 \%$. All other reagents were of analytical grade.

\subsection{Synthesis of $\beta$-Carotene-Chitooligosaccharides Complexes}

CAR-CHIOS complexes were prepared as previously described by Bockuviene and Sereikaite [21]. Briefly, the complexes named as LF4 and LF5 were obtained by the freeze-drying method. For LF4 synthesis, the suspension prepared from $10 \mathrm{mg}$ of CAR in $0.5 \mathrm{~mL}$ of ethanol and $10 \mathrm{mg}$ of CHIOS in $1 \mathrm{~mL}$ water were mixed using a magnetic stirrer for $48 \mathrm{~h}$ at $25^{\circ} \mathrm{C}$ under dark conditions. For LF5 preparation, instead of water, CHIOS were dissolved in $1 \mathrm{~mL}$ of acidic water solution (pH 4). Finally, the solvents were evaporated in an oven at $30^{\circ} \mathrm{C}$, and obtained fine powder was dissolved in $5 \mathrm{~mL}$ of deionised water, frozen at $-20^{\circ} \mathrm{C}$ and lyophilised.

The complexes named as S6 and S7 were prepared by the sonication method. For S6 synthesis, $10 \mathrm{mg}$ of CAR in $0.5 \mathrm{~mL}$ of ethanol and $10 \mathrm{mg}$ of CHIOS were dissolved in $1 \mathrm{~mL}$ of ethanol/water solution $(70 / 30, v / v)$ under magnetic stirring for $24 \mathrm{~h}$ in the dark at $25^{\circ} \mathrm{C}$. For S7 synthesis, $10 \mathrm{mg}$ of CAR in $0.5 \mathrm{~mL}$ of ethanol and $10 \mathrm{mg}$ of CHIOS in $1 \mathrm{~mL}$ acidic water solution (pH 4 ) were mixed. Subsequently, the solutions were sonicated using an ultrasound probe at $100 \mathrm{~W}$ for $30 \mathrm{~min}$, pulse treatment 30:30 on/off, and 60\% amplitude. Finally, the complexes paste were dried in an oven at $30{ }^{\circ} \mathrm{C}$ for $24 \mathrm{~h}$ and pulverised into a fine powder.

The complex named as KD3 was prepared by the kneading method. For KD3 synthesis, $10 \mathrm{mg}$ of $\mathrm{CAR}$ and $10 \mathrm{mg}$ of $\mathrm{CHIOS}$ were mixed in a ceramic mortar. Thereafter, the mixture was dissolved 
in $1 \mathrm{~mL}$ of degassed water/ethanol $(70 / 30, v / v)$ to obtain the paste, followed by grinding for $30 \mathrm{~min}$. The resulting paste was dried in an oven at $30^{\circ} \mathrm{C}$ for $24 \mathrm{~h}$ and pulverised into a fine powder.

All CAR-CHIOS complexes were dissolved in water and the solutions were centrifuged at $3000 \mathrm{rpm}$ (IKA mini G centrifuge, Staufen Germany) for $15 \mathrm{~min}$ to separate unreacted CAR and filtered through $0.45 \mu \mathrm{m}$ membrane filter. The solutions were dried in an oven at $30^{\circ} \mathrm{C}$ for $24 \mathrm{~h}$. All complexes prepared by three different techniques were stored in a refrigerator and protected from light.

\subsection{Stability of $\beta$-Carotene Complexed with CHIOS}

For the investigation of thermal and $\mathrm{pH}$ stability of $\beta$-carotene, CAR-CHIOS complexes $(1 \mathrm{mg} / \mathrm{mL})$ were dissolved in water and the $\mathrm{pH}$ was adjusted to the desired final value $(3,5,7$ or 8$)$ using either $\mathrm{NaOH}$ or $\mathrm{HCl}$ solution. For thermal stability experiments, the samples of $1 \mathrm{~mL}$ were transferred into glass tubes with caps and incubated in the dark at $40{ }^{\circ} \mathrm{C}, 60^{\circ} \mathrm{C}, 80$ and $100{ }^{\circ} \mathrm{C}$ for $30 \mathrm{~min}$. Then, the samples were cooled down in the ice bath to stop the reaction. For the investigation of $\mathrm{pH}$ stability, the samples of $1 \mathrm{~mL}$ into glass tubes with caps were stored in the dark at $24^{\circ} \mathrm{C}$ and $4{ }^{\circ} \mathrm{C}$ and in the light at $24^{\circ} \mathrm{C}$ for 30 days. For the investigation of the effect of UV irradiation on the chemical degradation of $\beta$-carotene in the complexes, the solution of CAR-CHIOS complexes $(1 \mathrm{mg} / \mathrm{mL})$ was prepared at different $\mathrm{pH}$ values $(3,5,7$ and 8$)$ and exposed to the irradiation produced by a UVC lamp (Philips, Amsterdam, Holland, $254 \mathrm{~nm}, 15 \mathrm{~W}$ ) at the distance of $35 \mathrm{~cm}$ in the dark at $24{ }^{\circ} \mathrm{C}$. The samples were analysed after 15, 30, 120 and 240 min of UV irradiation.

In all stability experiments, the chemical degradation of $\beta$-carotene was monitored by the registration of absorbance at $450 \mathrm{~nm}$ [28]. All stability experiments were performed in triplicate, and the relative stability was calculated using the following equation: Relative stability $\left.(\%)=\left(A_{t}\right) / A_{0}\right) \times$ 100 , where $A_{0}$ and $A_{t}$ are the absorbance of CAR-CHIOS solution at the initial moment and at the time $t$, respectively. For the calculation of the first-order rate constant of the degradation reaction $(k)$ and reaction half-life $\left(t_{1 / 2}\right)$, the data were fitted to the Equation (1) using the SigmaPlot 14 software, where $c_{t}$ is $\beta$-carotene concentration at the time $t$ under the storage conditions (in the dark at $4{ }^{\circ} \mathrm{C}$ and $24{ }^{\circ} \mathrm{C}$, in the light at $24^{\circ} \mathrm{C}$ or under UV irradiation at $254 \mathrm{~nm}$ ) and $c_{\mathrm{o}}$ is the initial concentration of $\beta$-carotene.

$$
c_{t}=c_{o} \exp (-k t)
$$

Dynamic light scattering method (DLS) was used for the evaluation of changes of hydrodynamic diameter of CAR-CHIOS complexes under different storage conditions. The hydrodynamic diameter of CAR-CHIOS complexes was measured using Zetasizer Nano ZS (Malvern Instruments) equipped with a $4 \mathrm{~mW}$ HeNe laser at a wavelength of $633 \mathrm{~nm}$. The measurements of the intensity of scattered light were performed at $25^{\circ} \mathrm{C}$ and at an angle of $173^{\circ}$. The size distribution data were analysed by the Malvern Zetasizer software 7.03 (Malvern Panalytical, Malvern, UK).

\subsection{Colour Measurement}

The chromatic characteristics of samples under the storage in the dark at $4{ }^{\circ} \mathrm{C}$ were evaluated using a hand-held spectrophotometer Konica Minolta CM-700d. The CIELAB colour space coordinates $L^{*}$ (for the lightness from black (0) to white (100)), $a^{*}$ (from green $(-)$ to red $\left.(+)\right), b^{*}$ (from blue (-) to yellow $(+))$ were measured using the illuminant $\mathrm{D}_{65}$. The spectrophotometer was calibrated against a white background. Then, the samples were placed onto a transparent glass plate with white background, and colour measurements were performed in triplicate. The colour assessment was performed periodically during 120 days. The Chroma or colour saturation $\left(C^{*} \mathrm{ab}\right)$, Hue angle $\left(h^{*} \mathrm{ab}\right)$ and the total colour difference $\left(\Delta E_{\mathrm{ab}}^{*}\right)$ were calculated as previously described [29].

\subsection{Statistical Analysis}

Data are presented as mean \pm standard deviation $(n=3)$. One-way analysis of variance (ANOVA, $p<0.05)$ was used to compare the data and define statistically significant result. 


\section{Results and Discussion}

\subsection{The Effect of Temperature on $\beta$-Carotene-Chitooligosaccharides Complexes}

About $60 \%$ of CAR complexed with CHIOS degraded under the storage at $100{ }^{\circ} \mathrm{C}$ for $30 \mathrm{~min}$ (Figure 1). Moreover, the increase in particle hydrodynamic diameter about of $20 \%$ comparing with fresh prepared complexes was registered. The most likely reason of that is the aggregation of degraded complexes and the changes in Van der Waals interactions in CHIOS molecules [22]. At $40{ }^{\circ} \mathrm{C}$ and $60{ }^{\circ} \mathrm{C}$ the complexes were more stable and the loss of CAR was about $20 \%$. Moreover, the temperature stability of $\beta$-carotene complexed with $\mathrm{CHIOS}$ was not practically dependent on $\mathrm{pH}$ value of solution. Previously, the thermal degradation of $0.1 \%(w / v) \beta$-carotene dissolved in ethyl acetate was investigated [28]. After the incubation of solution at 60 and $80{ }^{\circ} \mathrm{C}$ for $30 \mathrm{~min}$, about 50 and $20 \%$ of $\beta$-carotene retained, respectively. Therefore, the complexation of $\beta$-carotene with $\mathrm{CHIOS}$ obviously increases its thermal stability (Figure 1). The degradation of $\beta$-carotene at high temperatures is mainly due to oxidation [30]. Supposedly, for the complex formation, CAR entraps into CHIOS chains being helical in shape, and the supramolecular system of the complexes forms [21]. The three-dimensional network of matrix can act as a physical barrier protecting $\beta$-carotene. Moreover, $\mathrm{CHIOS}$ have an antioxidant activity [31] and can prevent $\beta$-carotene from oxidation. However, KD3 complex prepared by the kneading method exhibited significantly lower stability at the higher temperature comparing with the complexes LF4, LF5 and S6, S7 prepared by freeze-drying and sonication methods, respectively.

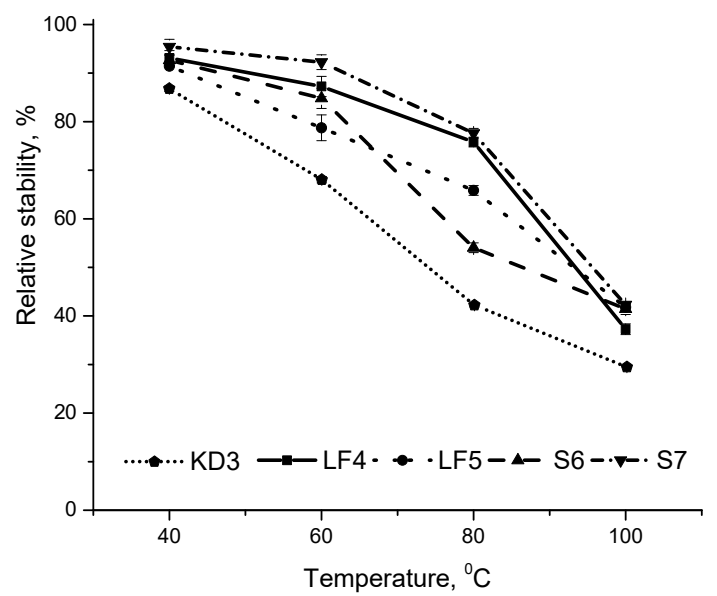

Figure 1. Thermal stability of CAR during thermal treatment of CAR-CHIOS complexes KD3, LF4, LF5, $\mathrm{S} 6$ and $\mathrm{S} 7 \mathrm{in}$ the dark for $30 \mathrm{~min}$ at various temperatures and neutral $\mathrm{pH}$. Each value was expressed as mean \pm standard deviation $(n=3)$.

\subsection{The Effect of $p H$ and Temperature on the Long-Term Stability of Complexed $\beta$-Carotene}

The $\mathrm{pH}$ influence on the long-term stability of CAR complexed with CHIOS was investigated under the storage in the dark at $4{ }^{\circ} \mathrm{C}$ and $24{ }^{\circ} \mathrm{C}$ and in the light at $24{ }^{\circ} \mathrm{C}$ (Figure 2, Figures S1 and $\mathrm{S} 2$ ). The first-order rate constants of the reaction of $\beta$-carotene degradation and the half-lives were calculated under different conditions of the storage (Table 1). The applicability of the first-order kinetics model for $\beta$-carotene degradation was previously reported $[32,33]$. Under the storage in the dark at $4{ }^{\circ} \mathrm{C}$, the kinetics parameters of $\beta$-carotene degradation were significantly dependent on the $\mathrm{pH}$ values. The lowest stability was determined for KD3 complex at all pH values comparing with the complexes prepared by freeze-drying and sonication methods. The complexes S6 and S7 exhibited the highest stability at $\mathrm{pH}$ 5. Obtained results are very important having in mind the possible application of complexes as CAR delivery system for the fortification of food with various $\mathrm{pH}$ values. The sensitivity of carotenoids to acids is related with the formation of carbocations of carotenoid molecules [34]. Chitooligosaccharides molecules having the protonated amino groups at the acid and slightly acid 
environment [35] probably create an electrostatic barrier for the protonation of a carotenoid molecule. The size of complexes and polydispersity index under all storage conditions for 30 days also changed insignificantly. In the dark, all complexes were less stable at $24{ }^{\circ} \mathrm{C}$ than at $4{ }^{\circ} \mathrm{C}$ temperature of storage. At $24{ }^{\circ} \mathrm{C}$, the changes of the stability of complexes LF4 and LF5 were insignificant in the pH range 3-8. The complexes $\mathrm{S} 6$ and $\mathrm{S} 7$ exhibited the highest stability at $\mathrm{pH} 3$, and the differences in the stability were insignificant in the $\mathrm{pH}$ range $5-8$. It seems that in the dark at $24{ }^{\circ} \mathrm{C}$ the degradation of $\beta$-carotene is more influenced by the temperature of storage than by $\mathrm{pH}$ value.
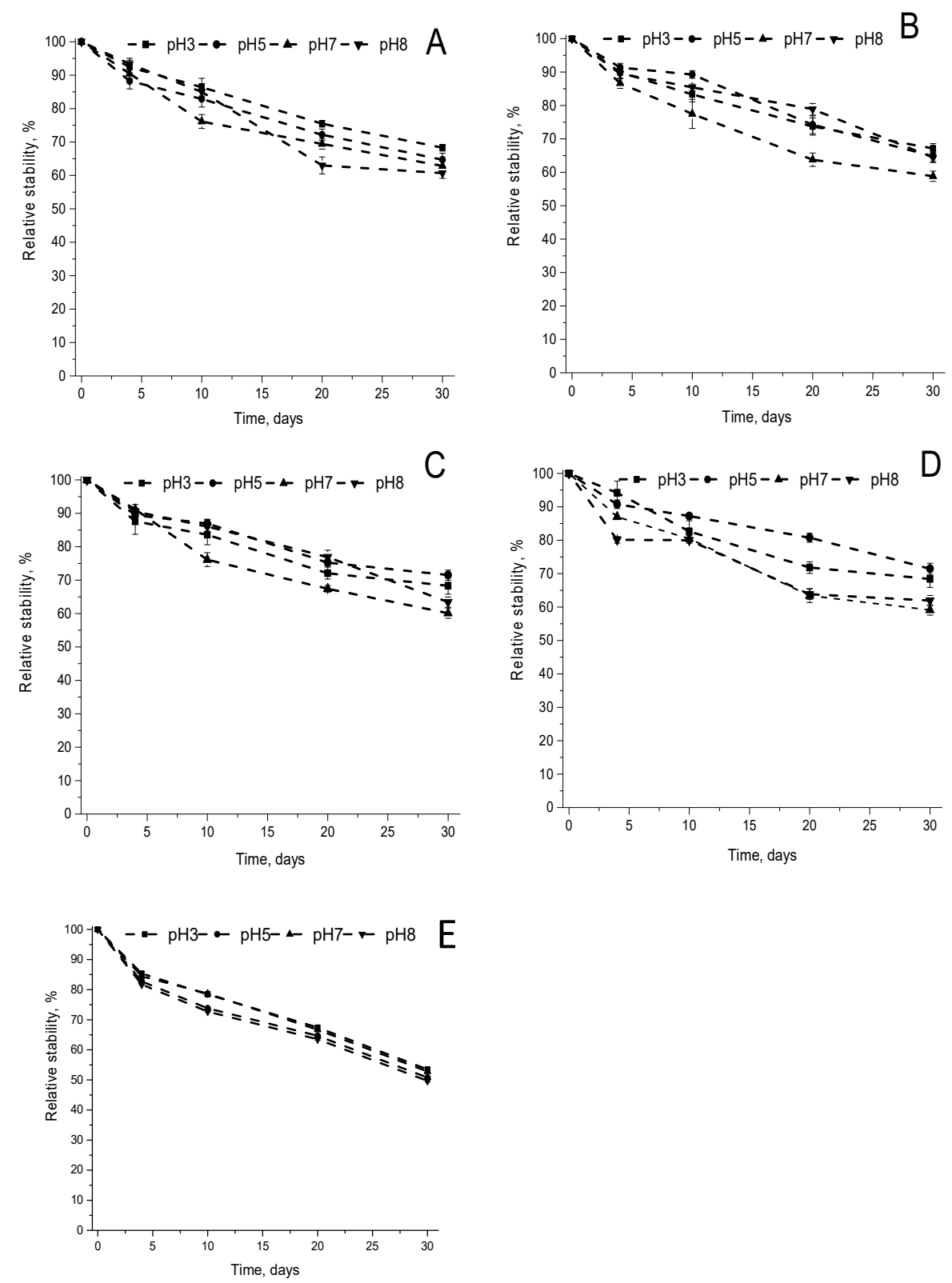

Figure 2. The effect of $\mathrm{pH}$ on CAR stability during the storage of CAR-CHIOS complexes LF4 (A), LF5 (B), S6 (C), S7 (D) and KD3 (E) in the dark at $4{ }^{\circ} \mathrm{C}$. Each value was expressed as mean \pm standard deviation $(n=3)$. 
Table 1. First-order kinetics parameters for CAR-CHIOS complexes degradation under different conditions ${ }^{1,2,3}$.

\begin{tabular}{|c|c|c|c|c|c|c|c|c|c|}
\hline \multirow{2}{*}{$\begin{array}{l}\text { Storage } \\
\text { Conditions }\end{array}$} & \multirow{2}{*}{ Sample } & \multicolumn{8}{|c|}{$\mathrm{pH}$} \\
\hline & & 3 & 5 & 7 & 8 & 3 & 5 & 7 & 8 \\
\hline & & \multicolumn{4}{|c|}{$k \times 10^{3}$, day $^{-1}$} & \multicolumn{4}{|c|}{$t_{1 / 2}$, days } \\
\hline Dark at & KD3 & $14.38 \pm 0.26^{\mathrm{aA}}$ & $14.56 \pm 0.29 \mathrm{aB}$ & $16.47 \pm 0.48^{\mathrm{aC}}$ & $17.61 \pm 0.37 \mathrm{aD}$ & $48.83 \pm 0.57$ & $47.25 \pm 0.69$ & $42.76 \pm 0.35$ & $39.45 \pm 0.16$ \\
\hline \multirow[t]{5}{*}{$4^{\circ} \mathrm{C}$} & LF4 & $6.34 \pm 0.08^{\mathrm{bA}}$ & $8.24 \pm 0.06^{\mathrm{bB}}$ & $5.29 \pm 0.07^{b C}$ & $5.83 \pm 0.09 \mathrm{bD}$ & $109.34 \pm 0.54$ & $85.64 \pm 0.39$ & $133.88 \pm 0.56$ & $118.36 \pm 0.28$ \\
\hline & LF5 & $6.76 \pm 0.04^{\mathrm{cA}}$ & $8.33 \pm 0.05^{\mathrm{bB}}$ & $5.09 \pm 0.07^{b C}$ & $5.39 \pm 0.03^{\mathrm{cD}}$ & $102.46 \pm 0.24$ & $85.34 \pm 0.65$ & $120.33 \pm 0.29$ & $128.43 \pm 0.73$ \\
\hline & S6 & $6.15 \pm 0.05^{\mathrm{dA}}$ & $2.46 \pm 0.04^{\mathrm{cB}}$ & $4.88 \pm 0.01^{\mathrm{cC}}$ & $5.18 \pm 0.32 \mathrm{dD}$ & $122.45 \pm 0.93$ & $125.34 \pm 0.46$ & $140.43 \pm 0.73$ & $132.65 \pm 0.75$ \\
\hline & S7 & $6.23 \pm 0.02 \mathrm{dA}$ & $2.47 \pm 0.05^{\mathrm{cB}}$ & $4.88 \pm 0.08^{\mathrm{cC}}$ & $5.18 \pm 0.08 \mathrm{dD}$ & $118.75 \pm 0.31$ & $129.46 \pm 0.65$ & $145.56 \pm 0.22$ & $138.45 \pm 0.82$ \\
\hline & & \multicolumn{4}{|c|}{$k \times 10^{2}, \mathrm{dav}^{-1}$} & \multicolumn{4}{|c|}{$t_{1 / 2}$, days } \\
\hline Dark at & KD3 & $2.84 \pm 0.07 \mathrm{aA}$ & $3.91 \pm 0.08^{a B}$ & $2.95 \pm 0.04 \mathrm{aA}$ & $3.91 \pm 0.03 \mathrm{aB}$ & $24.59 \pm 0.48$ & $17.74 \pm 0.19$ & $23.94 \pm 0.59$ & $17.38 \pm 0.24$ \\
\hline \multirow[t]{4}{*}{$24^{\circ} \mathrm{C}$} & LF4 & $2.39 \pm 0.05^{b A}$ & $2.36 \pm 0.12^{b A}$ & $2.45 \pm 0.04 \mathrm{bA}$ & $2.33 \pm 0.05 \mathrm{bA}$ & $27.67 \pm 0.36$ & $27.06 \pm 0.43$ & $28.24 \pm 0.59$ & $29.84 \pm 0.63$ \\
\hline & LF5 & $2.49 \pm 0.05^{\mathrm{bA}}$ & $2.49 \pm 0.06^{\mathrm{bA}}$ & $2.35 \pm 0.04^{\mathrm{bA}}$ & $2.23 \pm 0.06^{\mathrm{bA}}$ & $27.56 \pm 0.79$ & $28.16 \pm 0.73$ & $29.18 \pm 0.28$ & $30.52 \pm 0.22$ \\
\hline & S6 & $1.89 \pm 0.01 \mathrm{cA}$ & $2.59 \pm 0.06^{b B}$ & $2.55 \pm 0.04 \mathrm{bB}$ & $2.73 \pm 0.05^{\mathrm{cB}}$ & $36.04 \pm 0.91$ & $26.77 \pm 0.74$ & $26.51 \pm 0.59$ & $25.48 \pm 0.79$ \\
\hline & S7 & $1.76 \pm 0.05^{\mathrm{cA}}$ & $2.39 \pm 0.04^{\mathrm{bB}}$ & $2.45 \pm 0.04 \mathrm{bB}$ & $2.43 \pm 0.05^{b B}$ & $35.76 \pm 0.70$ & $28.47 \pm 0.43$ & $28.75 \pm 0.69$ & $28.68 \pm 0.76$ \\
\hline Light at & KD3 & $6.97 \pm 0.99 \mathrm{aA}$ & $6.96 \pm 0.58 \mathrm{aA}$ & $6.95 \pm 0.63^{\mathrm{aA}}$ & $6.97 \pm 0.53^{\mathrm{aA}}$ & $9.83 \pm 0.48$ & $9.95 \pm 0.55$ & $9.98 \pm 0.64$ & $9.95 \pm 0.46$ \\
\hline \multirow[t]{4}{*}{$24^{\circ} \mathrm{C}$} & LF4 & $2.63 \pm 0.92^{\mathrm{bA}}$ & $3.05 \pm 0.85 \mathrm{bB}$ & $4.64 \pm 0.87 \mathrm{bC}$ & $3.69 \pm 0.65 \mathrm{bB}$ & $26.73 \pm 0.59$ & $22.49 \pm 0.68$ & $16.04 \pm 0.54$ & $18.78 \pm 0.68$ \\
\hline & LF5 & $2.58 \pm 0.97 \mathrm{bA}$ & $3.08 \pm 0.65^{b B}$ & $4.91 \pm 0.24^{\mathrm{cC}}$ & $3.98 \pm 0.51 \mathrm{bD}$ & $26.87 \pm 0.56$ & $22.48 \pm 0.68$ & $14.05 \pm 0.56$ & $17.31 \pm 0.79$ \\
\hline & S6 & $3.06 \pm 0.57 \mathrm{cA}$ & $3.09 \pm 0.84 \mathrm{bA}$ & $3.09 \pm 0.28 \mathrm{dA}$ & $3.05 \pm 0.75^{\mathrm{cA}}$ & $22.49 \pm 0.77$ & $22.81 \pm 0.41$ & $22.78 \pm 0.41$ & $22.54 \pm 0.43$ \\
\hline & S7 & $3.96 \pm 0.68 \mathrm{dA}$ & $3.13 \pm 0.59 \mathrm{bB}$ & $3.15 \pm 0.39 \mathrm{~dB}$ & $4.71 \pm 0.59 \mathrm{dC}$ & $17.65 \pm 0.85$ & $16.76 \pm 0.75$ & $16.71 \pm 0.86$ & $15.65 \pm 0.54$ \\
\hline \multirow{6}{*}{$\begin{array}{c}\text { UVC, dark } \\
\text { at } 24^{\circ} \mathrm{C}\end{array}$} & & \multicolumn{4}{|c|}{$k \times 10^{3}, \min ^{-1}$} & \multicolumn{4}{|c|}{$t_{1 / 2}, \min ^{-1}$} \\
\hline & KD3 & $25.95 \pm 5.84^{\mathrm{aA}}$ & $26.39 \pm 2.45^{\mathrm{aB}}$ & $26.76 \pm 3.85^{\mathrm{aC}}$ & $25.89 \pm 4.85 \mathrm{aD}$ & $26.71 \pm 0.54$ & $26.45 \pm 0.61$ & $25.90 \pm 0.46$ & $26.86 \pm 0.73$ \\
\hline & LF4 & $6.59 \pm 0.49 \mathrm{bA}$ & $6.04 \pm 0.54 \mathrm{bB}$ & $6.68 \pm 0.58^{\mathrm{bA}}$ & $6.50 \pm 0.64 \mathrm{bA}$ & $105.71 \pm 0.34$ & $114.45 \pm 0.61$ & $103.90 \pm 0.46$ & $105.86 \pm 0.63$ \\
\hline & LF5 & $12.92 \pm 0.45 \mathrm{cA}$ & $8.53 \pm 0.35^{c B}$ & $6.64 \pm 0.38^{\mathrm{bC}}$ & $6.08 \pm 0.66^{\mathrm{cD}}$ & $53.63 \pm 0.67$ & $80.98 \pm 0.54$ & $105.05 \pm 0.59$ & $115.95 \pm 0.62$ \\
\hline & S6 & $13.65 \pm 0.74 \mathrm{dA}$ & $9.19 \pm 0.47 \mathrm{~dB}$ & $9.11 \pm 0.46^{\mathrm{cB}}$ & $9.09 \pm 0.66 \mathrm{~dB}$ & $50.76 \pm 0.73$ & $75.96 \pm 0.65$ & $75.28 \pm 0.86$ & $76.42 \pm 0.87$ \\
\hline & S7 & $15.82 \pm 0.53 \mathrm{eA}$ & $9.16 \pm 0.79 \mathrm{~dB}$ & $9.18 \pm 0.77 \mathrm{cB}$ & $9.18 \pm 0.75 \mathrm{~dB}$ & $43.80 \pm 0.51$ & $75.61 \pm 0.68$ & $75.58 \pm 0.42$ & $75.31 \pm 0.54$ \\
\hline
\end{tabular}

Data are presented as mean \pm standard deviation $(n=3){ }^{2}$ The data were fitted to firstorder kinetics, the coefficient of conrelation $R$ was in the interval of $0.8286-0.9994 .{ }^{3}$ Different capital letters represent significant differences in the mean within the row and different lowercase letters represent significant differences within the column $(p<0.05)$. 
Under the storage in the light at $24^{\circ} \mathrm{C}$ (Figure S2), the KD3 complex prepared by the kneading method exhibited the lowest stability, which differed insignificantly in the $\mathrm{pH}$ range 3-8. Overall, the half-lives of all complexes decreased comparing with the storage conditions in the dark at $24{ }^{\circ} \mathrm{C}$. The complexes LF4 and LF5 prepared by freeze-drying method were unexpectedly more stable at the acid or slightly acid environment than at the neutral or slightly alkali medium. Overall, in the light at $24^{\circ} \mathrm{C}$ the half-lives of $\beta$-carotene degradation in all our complexes were in the range of 9.83-26.87 days, while the half-life of $\beta$-carotene dissolved in ethyl acetate was $18.16 \mathrm{~h}$ at $21^{\circ} \mathrm{C}$ [28]. The stabilization of $\beta$-carotene by the complexation with CHIOS is obvious.

\subsection{The Effect of UV Irradiation on $\beta$-Carotene-Chitooligosaccharides Complexes}

The most significant effect of UV irradiation on $\beta$-carotene degradation was found for the KD3 complex (Table 1, Figure S3). The complexes LF4 and LF5 obtained by the freeze-drying method were most stable, and the half-lives of $\beta$-carotene degradation were the longest. The degradation rate of $\beta$-carotene complexed with CHIOS was similar at all $\mathrm{pH}$ values for all complexes with the exception for the complexes $\mathrm{S} 6$ and $\mathrm{S} 7$ obtained by the sonication method. At the acid conditions ( $\mathrm{pH} 3$ ), $\beta$-carotene in that complexes degraded significantly faster comparing with other $\mathrm{pH}$ values. As can be seen, the complexes obtained by freeze-drying techniques were significantly more stable than by the sonication method. UV irradiation causes the production of free radicals and induces photochemical oxidation of compounds. CHIOS that wrap CAR are known as compounds having an antioxidant activity. Those antioxidant properties are closely related to the molecular mass of CHIOS and their amino and hydroxyl groups $[22,31,36]$. It is plausible that the sonication method induces changes in CHIOS molecules, and in consequence, the protective effect against the damage of CAR caused by UV irradiation reduces. The lower stability of $\beta$-carotene in KD3 complex under UV irradiation conditions as well under the long-term storage in the dark and in the light is probably also related to the changes in CHIOS structure induced by kneading. Therefore, freeze-drying method for complex preparation ensures the highest stability of $\beta$-carotene against the degradation by UV irradiation.

\subsection{The Changes of Colour Parameters of CAR-CHIOS Complexes}

The changes of colour parameters of complexes during their storage in the dark at $4{ }^{\circ} \mathrm{C}$ were monitored by non-destructive method measuring colour fading. The data are presented in Table 2 and Figure 3.

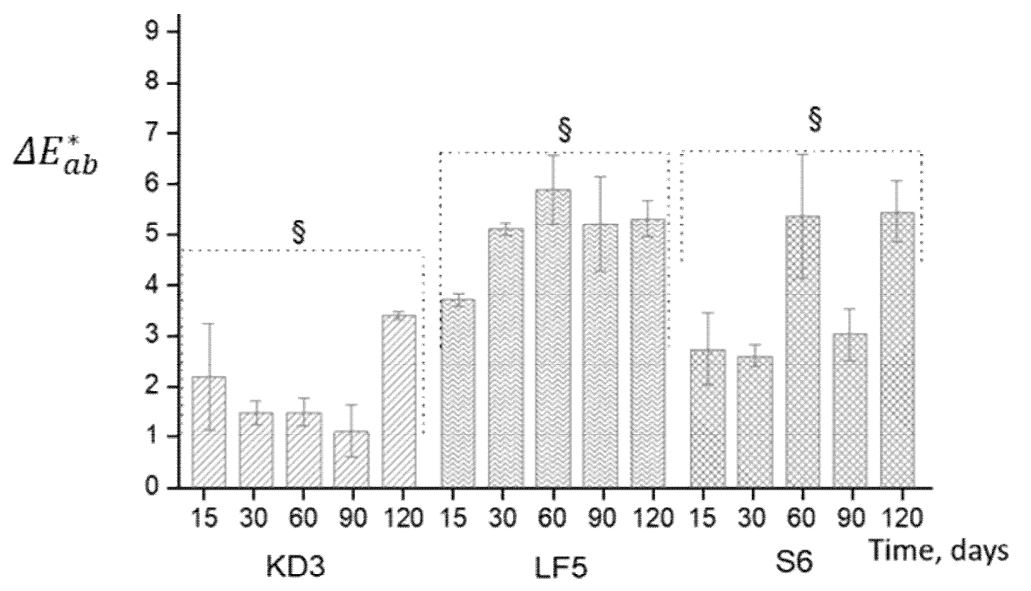

Figure 3. The total colour differences of CAR-CHIOS complexes KD3, LF5, S6 during the storage for 120 days in the dark at $4{ }^{\circ} \mathrm{C}$. Each value was expressed as mean \pm standard deviation $(n=3)$. Significant (§) differences of the values of colour parameter are determined using one-way analysis of variance (ANOVA, $p<0.05$ ). 
Table 2. The colour parameters of CAR-CHIOS complexes during the storage of 120 days in the dark at $4{ }^{\circ} \mathrm{C}^{1}$.

\begin{tabular}{|c|c|c|c|c|c|c|c|}
\hline Sample & Time, Days & $L^{*}$ & $a^{*}$ & $b^{*}$ & $a^{*} / b^{*}$ & $C^{*}{ }_{a b}$ & $h^{*}{ }_{a b}$ \\
\hline \multirow{7}{*}{ KD3 } & & $\S$ & $\S$ & $\S$ & $\S$ & $\S$ & $\S$ \\
\hline & 0 & $65.44 \pm 0.48$ & $4.24 \pm 0.3$ & $24.59 \pm 0.42$ & $0.17 \pm 0.01$ & $24.96 \pm 0.46$ & $80.23 \pm 0.56$ \\
\hline & 15 & $63.75 \pm 0.26$ & $3.86 \pm 0.18$ & $25.41 \pm 0.33$ & $0.15 \pm 0.01$ & $25.70 \pm 0.49$ & $81.31 \pm 0.33$ \\
\hline & 30 & $64.53 \pm 0.39$ & $4.81 \pm 0.24$ & $25.56 \pm 0.42$ & $0.18 \pm 0.01$ & $26.02 \pm 0.42$ & $79.34 \pm 0.54$ \\
\hline & 60 & $64.38 \pm 0.45$ & $5.09 \pm 0.71$ & $24.26 \pm 0.63$ & $0.20 \pm 0.02$ & $24.80 \pm 0.77$ & $78.12 \pm 0.48$ \\
\hline & 90 & $64.44 \pm 0.02$ & $4.31 \pm 0.16$ & $24.52 \pm 0.03$ & $0.17 \pm 0.01$ & $24.90 \pm 0.02$ & $80.02 \pm 0.30$ \\
\hline & 120 & $63.31 \pm 0.01$ & $3.16 \pm 0.01$ & $22.22 \pm 0.01$ & $0.14 \pm 0.02$ & $22.44 \pm 0.01$ & $81.83 \pm 0.02$ \\
\hline \multirow{7}{*}{ LF5 } & & $\S$ & $\S$ & $\S$ & $\S$ & $\S \S$ & $\S$ \\
\hline & 0 & $54.60 \pm 0.42$ & $13.49 \pm 0.49$ & $14.72 \pm 0.14$ & $0.91 \pm 0.03$ & $19.97 \pm 0.35$ & $47.50 \pm 1.06$ \\
\hline & 15 & $57.35 \pm 0.25$ & $15.37 \pm 0.29$ & $13.25 \pm 0.63$ & $1.16 \pm 0.04$ & $20.29 \pm 0.58$ & $40.76 \pm 1.07$ \\
\hline & 30 & $58.60 \pm 0.33$ & $16.63 \pm 0.35$ & $14.46 \pm 0.44$ & $1.15 \pm 0.02$ & $22.04 \pm 0.50$ & $41.01 \pm 0.71$ \\
\hline & 60 & $59.48 \pm 0.95$ & $16.62 \pm 0.26$ & $14.79 \pm 0.06$ & $1.12 \pm 0.02$ & $22.25 \pm 0.16$ & $41.68 \pm 0.57$ \\
\hline & 90 & $58.64 \pm 0.32$ & $16.54 \pm 0.37$ & $14.48 \pm 0.43$ & $1.14 \pm 0.03$ & $21.98 \pm 0.52$ & $41.37 \pm 1.05$ \\
\hline & 120 & $57.99 \pm 0.77$ & $16.38 \pm 0.32$ & $11.89 \pm 0.01$ & $1.37 \pm 0.02$ & $20.24 \pm 0.26$ & $40.67 \pm 0.33$ \\
\hline \multirow{6}{*}{ S6 } & 0 & $\begin{array}{c}\S \\
33.46 \pm 0.33\end{array}$ & $\begin{array}{c}\S \S \\
23.73 \pm 0.22\end{array}$ & $\begin{array}{c}\S \\
16.30 \pm 0.25\end{array}$ & $\begin{array}{c}\S \\
1.45 \pm 0.03\end{array}$ & $\begin{array}{c}\S \\
28.79 \pm 0.08\end{array}$ & $\begin{array}{c}\S \\
34.48 \pm 0.65\end{array}$ \\
\hline & 15 & $35.81 \pm 0.13$ & $24.40 \pm 0.64$ & $17.26 \pm 0.3$ & $1.41 \pm 0.09$ & $29.90 \pm 0.96$ & $35.31 \pm 1.85$ \\
\hline & 30 & $34.27 \pm 0.50$ & $24.92 \pm 0.88$ & $18.39 \pm 0.40$ & $1.35 \pm 0.07$ & $30.98 \pm 0.48$ & $36.43 \pm 1.55$ \\
\hline & 60 & $37.56 \pm 0.37$ & $24.63 \pm 0.50$ & $19.58 \pm 0.24$ & $1.25 \pm 0.04$ & $31.47 \pm 0.24$ & $38.48 \pm 0.93$ \\
\hline & 90 & $34.65 \pm 0.66$ & $24.54 \pm 0.56$ & $18.82 \pm 0.19$ & $1.30 \pm 0.04$ & $30.93 \pm 0.32$ & $37.50 \pm 0.92$ \\
\hline & 120 & $38.38 \pm 0.92$ & $25.42 \pm 0.01$ & $19.98 \pm 1.07$ & $1.27 \pm 0.07$ & $32.34 \pm 0.66$ & $38.15 \pm 1.50$ \\
\hline
\end{tabular}

${ }^{1}$ Insignificant $(\S \S)$ and significant $(\S)$ differences of the values of colour parameters in the column are determined using one-way analysis of variance (ANOVA, $p<0.05$ ).

As can be seen, the colour parameters of CAR-CHIOS complexes are different and depend on the methods of complexes preparation. As follows from the ratio $a^{*} / b^{*}$ and Hue angle, the colours of LF5 and S6 complexes are shifted to orange-red-orange tones, and the colour of KD3 is more orange-yellow [37]. During four months of storage the changes of colour parameters of the complexes are significant. However, the total colour differences $\Delta E^{*}$ ab are in the interval of 3.0-6.0 and qualified as appreciable, detectable by ordinary people, but not large [38]. It shows the utility of the complexation in the protection of $\beta$-carotene and the retention its colour.

\section{Conclusions}

To sum up, the complexation of $\beta$-carotene with chitooligosaccharides improved the temperature stability and ensured its long-term stability. In water solutions, the best characteristics were exhibited by the complexes prepared by freeze-drying and sonication methods. In the powder form, the complexes retained their colour for the period of the investigation of four months. The calculated total colour differences of the complexes were qualified as appreciable, detectable by ordinary people, but not large. Therefore, $\beta$-carotene-chitooligosaccharides complexes, which both components are approved as food additives, could be in future a new technology for $\beta$-carotene delivery and applied as a new formulation in food systems.

Supplementary Materials: The following are available online at http://www.mdpi.com/2304-8158/9/6/765/s1, Figure S1: The effect of $\mathrm{pH}$ on CAR stability during the storage of CAR-CHIOS complexes LF4 (A), LF5 (B), S6 (C), $\mathrm{S} 7(\mathrm{D})$ and $\mathrm{KD} 3(\mathrm{E})$ in the dark at $24^{\circ} \mathrm{C}$. Each value is expressed as mean \pm standard deviation $(n=3)$, Figure S2: The effect of $\mathrm{pH}$ on CAR stability during the storage of CAR-CHIOS complexes LF4 (A), LF5 (B), S6 (C), S7 (D) and KD3 (E) in the light at $24^{\circ} \mathrm{C}$. Each value is expressed as mean \pm standard deviation $(n=3)$, Figure S3: The stability of CAR during UV irradiation treatment of CAR-CHIOS complexes LF4 (A), LF5 (B), S6 (C), S7 (D) and $\mathrm{KD} 3(\mathrm{E})$ at different $\mathrm{pH}$ values. Each value is expressed as mean \pm standard deviation $(n=3)$.

Author Contributions: Conceptualization, J.S. and A.B.; methodology, A.B.; investigation, A.B.; writing-original draft preparation, A.B.; writing-review and editing, J.S.; supervision, J.S.; project administration, J.S.; funding acquisition, J.S. All authors have read and agreed to the published version of the manuscript.

Funding: This research was funded by the European Social Fund under the No 09.3.3-LMT-K-712 “Development of Competences of Scientists, other Researchers and Students through Practical Research Activities" measure. Grant No 09.3.3-LMT-K-712-02-0039.

Conflicts of Interest: The authors declare no conflict of interest. 


\section{References}

1. Rodriguez-Concepcion, M.; Avalos, J.; Bonet, L.; Boronat, A.; Gomez-Gomez, L.; Hornero-Mendez, D.; Limon, M.C.; Melendez-Martinez, A.J.; Olmedilla-Alonso, B.; Palou, A.; et al. A global perspective on carotenoids: Metabolism, biotechnology, and benefits for nutrition and health. Prog. Lipid Res. 2018, 70, 62-93. [CrossRef] [PubMed]

2. Melendez-Martinez, A.J. An overview of carotenoids, apocarotenoids, and vitamin A in agro-food, nutrition, health, and disease. Mol. Nutr. Food Res. 2019, 63, 1801045. [CrossRef] [PubMed]

3. Sandmann, G. Antioxidant protection from UV- and light-stress related to carotenoid structures. Antioxidants 2019, 8, 219. [CrossRef] [PubMed]

4. Neves, M.F.; Cunha, M.R.; de Paula, T. Effects of nutrients and exercises to attenuate oxidative stress and prevent cardiovascular disease. Curr. Pharm. Des. 2018, 24, 4800-4806. [CrossRef]

5. Jayedi, A.; Rashidy-Pour, A.; Parohan, M.; Zargar, M.S.; Shab-Bidar, S. Dietary and circulating vitamin C, vitamin $\mathrm{E}, \beta$-carotene and risk of total cardiovascular mortality: A systematic review and dose-response meta-analysis of prospective observational studies. Public Health Nutr. 2019, 22, 1872-1887. [CrossRef] [PubMed]

6. Ruiz, R.B.; Hernandez, P.S. Cancer chemoprevention by dietary phytochemicals: Epidemiological evidence. Maturitas 2016, 94, 13-19. [CrossRef] [PubMed]

7. Mokbel, K.; Mokbel, K. Chemoprevention of breast cancer with vitamins and micronutrients: A concise review. In Vivo 2019, 33, 983-997. [CrossRef]

8. Sluijs, I.; Cadier, E.; Beulens, J.W.J.; Spijkerman, A.M.W.; van der Schow, Y.T. Dietary intake of carotenoids and risk of type 2 diabetes. Nutr. Metab. Cardiovasc. Dis. 2015, 25, 376-381. [CrossRef]

9. Quansah, D.Y.; Ha, K.; Jun, S.; Kim, S.A.; Shin, S.; Wie, G.A.; Joung, H. Associations of dietary and risk of type 2 diabetes: Data from the 2007-2012 Korea National health and nutrition examination survey. Molecules 2017, 22, 1664. [CrossRef] [PubMed]

10. Carneiro, A.; Andrade, J.P. Nutritional and lifestyle interventions for age-related macular degeneration: A review. Oxid. Med. Cell. Longev. 2017, 2017, 6469138.

11. Khoo, H.E.; Ng, H.S.; Yap, W.S.; Goh, H.J.H.; Yim, Y.S. Nutrients for prevention of macular degeneration and eye-related diseases. Antioxidants 2019, 8, 85. [CrossRef] [PubMed]

12. Scita, G. The stability of $\beta$-carotene under different laboratory conditions. J. Nutr. Biochem. 1992, 3, $124-128$. [CrossRef]

13. Berset, C.; Marty, C. Formation of non-volatile compounds by thermal degradation of $\beta$-carotene: Protection by antioxidants. Methods Enzymol. 1992, 213, 129-142.

14. Mehrad, B.; Ravanfar, R.; Licker, J.; Regenstein, J.M. Enhancing the physicochemical stability of $\beta$-carotene solid lipid nanoparticle (SLNP) using whey protein isolate. Food Res. Int. 2018, 105, 962-969. [CrossRef] [PubMed]

15. Du, Y.; Bao, C.; Huang, J.; Jiang, P.; Jiao, L.; Ren, F.; Li, Y. Improved stability, epithelial permeability and cellular antioxidant activity of $\beta$-carotene via encapsulation by self-assembled $\alpha$-lactalbumin micelles. Food Chem. 2019, 271, 707-714. [CrossRef] [PubMed]

16. Fu, D.; Deng, S.; McClements, D.J.; Zhou, L.; Zou, L.; Yi, J.; Liu, C.; Liu, W. Encapsulation of $\beta$-carotene in wheat gluten nanoparticle-xanthan gum-stabilized Pickering emulsions: Enhancement of carotenoid stability and bioaccessibility. Food Hydrocoll. 2019, 89, 80-89. [CrossRef]

17. Choi, S.J.; McClements, D.J. Nanoemulsions as delivery systems for lipophilic nutraceuticals: Strategies for improving their formulation, stability, functionality and bioavailability. Food Sci. Biotechnol. 2020, 29, 149-168. [CrossRef] [PubMed]

18. Mao, L.; Wang, D.; Liu, F.; Gao, Y. Emulsion design for the delivery of $\beta$-carotene in complex food systems. Crit. Rev. Food Sci. Nutr. 2017, 58, 770-784. [CrossRef] [PubMed]

19. Kong, L.; Bhosale, R.; Ziegler, G.R. Encapsulation and stabilization of b-carotene by amylose inclusion complexes. Food Res. Int. 2018, 105, 446-452. [CrossRef]

20. Chen, L.; Bai, G.; Yang, R.; Zang, J.; Zhou, T.; Zhao, G. Encapsulation of $\beta$-carotene within ferritin nanocages greatly increases its water-solubility and thermal stability. Food Chem. 2014, 149, 307-312. [CrossRef]

21. Bockuviene, A.; Sereikaite, J. Preparation and characterisation of novel water-soluble $\beta$-carotene-chitooligosaccharides complexes. Carbohydr. Polym. 2019, 225, 115226. [CrossRef] [PubMed] 
22. Phil, L.; Naveed, M.; Mohammad, I.S.; Bo, L.; Bin, D. Chitooligosaccharide: An evaluation of physicochemical and biological properties with the proposition for determination of thermal degradation products. Biomed. Pharmacother. 2018, 102, 438-451. [CrossRef] [PubMed]

23. Marmouzi, I.; Ezzat, S.M.; Salama, M.M.; Merghany, R.M.; Attar, A.M.; EL-Desoky, A.M.; Mohamed, S.O. Recent Updates in pharmacological properties of chitooligosaccharides. Biomed Res. Int. 2019, 2019, 4568039. [CrossRef] [PubMed]

24. Jiang, T.; Xing, X.; Zhang, L.; Liu, Z.; Zhao, J.; Liu, X. Chitosan oligosaccharides show protective effects in coronary heart disease by improving antioxidant capacity via the increase in intestinal probiotics. Oxid. Med. Cell. Longev. 2019, 2019, 7658052. [CrossRef] [PubMed]

25. Khan, F.; Lee, J.W.; Pham, D.T.N.; Kim, Y.M. Chitooligosaccharides as antibacterial, antibiofilm, antihemolytic and anti-virulence agent against Staphylococcus aureus. Curr. Pharm. Biotechnol. 2019, 20, 1223-1233. [CrossRef] [PubMed]

26. Bellich, B.; D'Agostino, I.; Semeraro, S.; Gamini, A.; Cesaro, A. "The Good, the Bad and the Ugly" of chitosans. Mar. Drugs 2016, 14, 99. [CrossRef] [PubMed]

27. Polyakov, N.E.; Leshina, T.V.; Meteleva, E.S.; Dushkin, A.V.; Konovalova, T.A.; Kispert, L.D. Water soluble complexes of carotenoids with arabinogalactan. J. Phys. Chem. B 2009, 113, 275-282. [CrossRef] [PubMed]

28. Chen, H.; Zhong, Q. Thermal and UV stability of $\beta$-carotene dissolved in peppermint oil microemulsified by sunflower lecithin and Tween 20 blend. Food Chem. 2015, 174, 630-636. [CrossRef] [PubMed]

29. Pathare, P.B.; Opara, U.L.; Al-Said, F.A.-J. Colour measurement and analysis in fresh and processed foods: A review. Food Bioproc. Technol. 2013, 6, 36-60. [CrossRef]

30. Knockaert, G.; Pulissery, S.K.; Lemmens, L.; Van Buggenhout, S.; Hendrickx, M.; Van Loey, A. Carrot $\beta$-carotene degradation and isomerization kinetics during thermal processing in the presence of oil. J. Agric. Food Chem. 2012, 60, 10312-10319. [CrossRef]

31. Ngo, D.-H.; Wijesekara, I.; Vo, T.-S.; Tan, Q.V.; Kim, S.-K. Marine food-derived functional ingredients as potential antioxidants in the food industry: An overview. Food Res. Int. 2011, 44, 523-529. [CrossRef]

32. Lim, A.S.L.; Griffin, C.; Roos, Y.H. Stability and loss kinetics of lutein and $\beta$-carotene encapsulated in freeze-dried emulsions layered interface and trehalose as glass former. Food Res. Int. 2014, 62, 403-409. [CrossRef]

33. Da Silva, M.M.; Paese, K.; Guterrese, S.S.; Pohlmann, A.R.; Rutz, J.K.; Cantillano, R.F.F.; Nora, L.; de Oliveira Rios, A. Thermal and ultraviolet-visible light stability kinetics of co-nanocapsulated carotenoids. Food Bioprod. Process. 2017, 105, 86-94. [CrossRef]

34. Boon, C.S.; McClements, D.J.; Weiss, J.; Decker, E.A. Factors influencing the chemical stability of carotenoids in foods. Crit. Rev. Food Sci. Nutr. 2010, 50, 515-532. [CrossRef] [PubMed]

35. Lodhi, G.; Kim, Y.-S.; Hwang, J.-W.; Kim, S.-K.; Jeon, Y.-J.; Je, J.-Y.; Ahn, C.-B.; Moon, S.-H.; Jeon, B.-T.; Park, P.-J. Chitooligosaccharide and its derivatives: Preparation and biological applications. BioMed Res. Int. 2014, 654913. [CrossRef] [PubMed]

36. Je, J.-Y.; Park, P.-J.; Kim, S.-K. Free radical scavenging properties of heterochitooligosaccharides using ESR spectroscopy. Food Chem. Toxicol. 2004, 42, 381-387. [CrossRef] [PubMed]

37. Dini, M.; Raseira, M.d.C.B.; Scariotto, S.; Carra, B.; de Abreu, E.S.; Mello-Farias, P.; Cantillano, R.F.F. Color shade heritability of peach flesh. J. Agric. Sci. 2019, 11, 236-247. [CrossRef]

38. Yamauchi, J. Handbook of Colour Science; Japanese Academy of Colour Science: Tokyo, Japan, 1989.

(C) 2020 by the authors. Licensee MDPI, Basel, Switzerland. This article is an open access article distributed under the terms and conditions of the Creative Commons Attribution (CC BY) license (http://creativecommons.org/licenses/by/4.0/). 